\title{
Effect of Rheumatoid Factor on
}

\section{Complement-Mediated Phagocytosis}

\author{
F. C. McDuffie and H. W. Brumfield \\ From the Departments of Medicine and Microbiology, Mayo Clinic and Mayo \\ Foundation, Rochester Minnesota 55901
}

A B S T R A C T The frequency and amount of IgM rheumatoid factor (RF) in the blood of patients with rheumatoid arthritis (RA) correlate with the severity of the disease and the number of complications. Though previous studies of RF in subacute bacterial endocarditis have shown that RF inhibits phagocytosis of microorganisms by granulocytes, the presence of low levels of complement $(\mathrm{C})$ in blood and synovial fluid of patients with the highest titers of RF suggests that an interaction between $\mathrm{RF}$ and $\mathrm{C}$ may contribute to the inflammatory process in RA. We thus employed a quantitative methodology to examine the effect of RF on complement-dependent phagocytosis of sheep erythrocytes by rabbit granulocytes. Addition of 2500 molecules of IgM RF to sheep cells heavily coated with IgG antibody (195,000 molecules per cell) resulted in virtually complete inhibition of uptake of $\mathrm{C} 3\left(\boldsymbol{\beta}_{1 \mathrm{c}}\right)$ and prevention of phagocytosis, an effect resulting from inhibition of uptake of $\mathrm{C} 1$ by the cells. When erythrocytes coated with only 34,000 molecules of IgG antibody were employed, phagocytosis was similarly inhibited. However the effect of RF on such cells was shown to be primarily mediated through inhibition of $\mathrm{C} 4$ rather than $\mathrm{C} 1$ uptake. Although the results do not exclude the participation of an IgM RF of higher avidity, present only in the tissues in rheumatoid inflammation, circulating IgM RF probably does not play a potentiating role in rheumatoid inflammation.

\section{INTRODUCTION}

Whether rheumatoid factor (RF) ${ }^{\mathbf{1}}$ (anti-IgG antibodies present in the sera of most patients with rheumatoid ar-

This work was presented in part at the 17 th Interim Scientific Session of the American Rheumatism Association, 10 December 1971.

Received for publication 27 March 1972 and in revised form 25 July 1972.

${ }^{1}$ Abbreviations used in this paper: C, complement; EM, thritis $[\mathrm{RA}])$ contributes to the pathogenesis of the inflammation of synovium or other tissues in this disease is not known. Though the experiments of Hollander and his collaborators $(1,2)$ (who found that injection of autologous IgG into quiescent joints could produce exacerbations of synovitis) were interpreted on the basis of an immune complex reaction between injected $\mathrm{IgG}$ and RF, this work has not been successfully repeated (3). Davis has postulated that RF may actually inhibit inflammation produced by immune complexes (4). In support of this latter concept Messner and his associates (5) found that IgM RF isolated from patients with subacute bacterial endocarditis was able to inhibit polymorphonuclear leukocyte phagocytosis of the infecting organisms coated with 7S IgG antibody. The inhibitory effect observed seemed to be primarily directed at the phagocytosis-promoting effect of fresh normal serum.

In the present study we have pursued the question of the effect of IgM RF on complement-mediated phagocytosis employing a quantitative methodology aimed at defining the effect with respect to quantities of antibody and RF involved as well as seeking to identify the point in the complement sequence at which RF acts. The results show that IgM RF does inhibit complement-mediated phagocytosis by blocking fixation of both $\mathrm{C} 1$ and $\mathrm{C} 4$. Interference with $\mathrm{C} 1$ fixation predominates at high levels of IgG antibody whereas interference with $\mathrm{C} 4$ fixation plays an important role at lower levels of antibody.

\section{METHODS}

Antibodies and immunoglobulins. IgM RF was prepared from a pool of five sera containing high titers of RF. All five donors to this pool had active RA at the time of bleeding and RF titers by latex fixation tests were from $1: 2,500$ to $1: 10,000$. After ultracentrifugation for $60 \mathrm{hr}$ at $200,000 \mathrm{~g}$ at a density of 1.250 (a-hieved by addition of sodium bromide) to remove lipoprotein, the lower layer was dialyzed against $\mathrm{pH} \quad 7.0 \quad 0.01 \mathrm{M}$ phosphate buffer to pre-

effective molecule; RA, rheumatoid arthritis; RF, rheumatoid factor. 


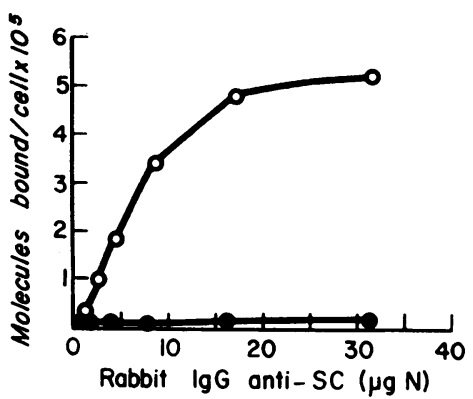

Figure 1 Binding of rabbit ${ }^{125}$ I-labeled IgG to sheep erythrocytes (E); IgG added to $5 \times 10^{7} \mathrm{E}$. (O), anti-sheep cell $\operatorname{IgG} ;(\bullet)$, normal $\operatorname{IgG}$.

cipitate the euglobulin. The precipitate was dissolved in $\mathrm{pH}$ 8.0 Tris $(0.1 \mathrm{M}), \mathrm{NaCl}(0.2 \mathrm{M})$ buffer, and the $\mathrm{IgM}$ fraction isolated by chromatography on Sephadex G-200. In order to eliminate small amounts of $\operatorname{IgG}$ bound to $\mathrm{RF}$ the rheumatoid IgM was further purified by sucrose density gradient ultracentrifugation in a $5-20 \%$ sucrose gradient in $\mathrm{pH} 3.5,0.1 \mathrm{~m}$ glycine buffer. Final yield of $\mathrm{IgM}$ from the original pool was about $10 \%$. Normal IgM was similarly prepared from a pool of two sera.

The IgG fraction from rabbit serum was prepared by chromatography of a $50 \%$ saturated ammonium sulfate precipitate of normal or immune rabbit serum on DEAE-cellulose (DE-32, Whatman) at $\mathrm{pH} \mathrm{8.5,0.01} \mathrm{Tris} \mathrm{buffer} \mathrm{plus}$ additional $\mathrm{NaCl}$ to achieve a relative salt concentration of $0.04 \mathrm{M}$ (conductivity, 4500 reciprocal $\Omega$ at $25^{\circ} \mathrm{C}$ ). The antiserum was a pool from five rabbits immunized intravenously with whole sheep cells.

Complement components. Guinea pig $\mathrm{C} 1$ and $\mathrm{C} 2$ were purified according to the method of Nelson, Jensen, Gigli, and Tamura (6). Human C3 $\left(\beta_{1 \mathrm{c}}\right)$ was isolated by chromatography on TEAE- or DEAE-cellulose according to the method of Müller-Eberhard and his associates $(7,8)$. Chromatography on hydroxyapatite as used by these workers for final purification of $\beta_{1 \mathrm{c}}$ did not prove to be a reproducible method in our hands for eliminating the major contaminant, C5, while still preserving full C3 activity. However our final preparation from DEAE-cellulose contained less than $5 \%$ contamination by $\mathrm{C} 5$ as determined by radial immunodiffusion analysis. Human $\mathrm{C} 4$ was prepared by the method of Müller-Eberhard and Biro (9). The final preparations contained small amounts of $\mathrm{Cl}$ inhibitor (less than 1 effective molecule per 100 effective molecules of C4).

Complement titrations. All titrations were carried out in tubes by modifications of the basic methodology of Mayer (10) except that one-half of all the recommended volumes were used and all tubes contained $7.5 \times 10^{2}$ sheep erythrocytes. $\mathrm{Cl}$ was titered with $\mathrm{EAC}_{4}$, prepared by removing $\mathrm{C} 1$ from $\mathrm{EAC}_{1,4}$ by incubation in $\mathrm{pH} 7.5$ barbital buffer, $0.075 \mathrm{M}$ relative $\mathrm{NaCl}$ and $0.01 \mathrm{M} E D T A$, at $37^{\circ} \mathrm{C}$ for $10 \mathrm{~min}$ followed by an additional incubation after washing at $0^{\circ} \mathrm{C}$ for $12 \mathrm{hr}$. C2 was measured with $\mathrm{EAC}_{1,4}$ prepared by incubating EA with 1000 effective molecules (EM) C1 per cell followed by addition of $50 \mathrm{EM} \mathrm{C4}$ per cell. For $\mathrm{C} 4$ determination $\mathrm{EAC}_{1}$, made by addition to EA of $1000 \mathrm{EM} \mathrm{C1}$ per cell (200350 EM $\mathrm{C} 1$ actually bound per cell as determined by $\mathrm{Cl}$ transfer test [11]), was employed. C3 $\left(\beta_{1 \mathrm{c}}\right)$ was measured by immune adherence of $\mathrm{EAC}_{1,4,2}$ (12) in microtiter plates. Serial dilutions of sample in $0.025 \mathrm{ml}$ glucose-veronal buffer (6) were first made. Then $0.025 \mathrm{ml}$ of $\mathrm{EAC}_{1,4,2}, 4 \times 10^{7} /$ $\mathrm{ml}$, were added, these having been prepared by addition of $75 \mathrm{EM}$ of $\mathrm{C} 2$ per cell to $\mathrm{EAC}_{1,4}$. After $10 \mathrm{~min}$ at $37^{\circ} \mathrm{C}$, $0.025 \mathrm{ml}$ of a suspension of human erythrocytes, $4 \times 10^{7} / \mathrm{ml}$, in barbital buffer containing $0.01 \mathrm{M}$ EDTA was added, together with $0.025 \mathrm{ml}$ of $0.4 \mathrm{M} \mathrm{NaCl}$. The cells were mixed and allowed to settle for $2 \mathrm{hr}$, at which time the agglutination patterns were read.

Radiolabeling. Rabbit IgG, human $\operatorname{IgM}$, and human $\mathrm{C} 3$ were all labeled with ${ }^{125} \mathrm{I}$ in order to measure the amounts bound to cells or antibody. The chloramine $T$ method as described by McConahey and Dixon (13) was used for this purpose. IgG and $\mathrm{C} 3$ retained full antibody and immune adherence activity respectively when labeled by this technique with $1 \mathrm{mCi}{ }^{125} \mathrm{I} / \mathrm{mg}$ protein. IgM, however, was found to be very labile upon iodination. Part of the difficulty was traced to the excess of reducing agent, $\mathrm{Na}_{2} \mathrm{~S}_{2} \mathrm{O}_{5}$, added to stop the iodination reaction. By using only just sufficient $\mathrm{Na}_{2} \mathrm{~S}_{2} \mathrm{O}_{5}$ to neutralize the amount of chloramine $\mathrm{T}$ added, reduction of $\operatorname{IgM}$ no longer occurred. In addition it was found desirable to reduce the amount of ${ }^{125} \mathrm{I}$ to $0.05 \mathrm{mCi}$ ${ }^{125} \mathrm{I} / \mathrm{mg} \mathrm{IgM}$ and to keep the reaction time to $1 \mathrm{~min}$ at room temperature. The number of atoms of carrier-free ${ }^{125} \mathrm{I}$ bound per molecule protein was about $5 \times 10^{-3}$ to $1 \times 10^{-2}$ for $\operatorname{IgM}$ and $\operatorname{IgG}$ and $5 \times 10^{-2}$ to $1 \times 10^{-1}$ for C3. The immune adherence titer per milligram of $\beta_{1 \mathrm{c}}$ of each $\mathrm{C} 3$ preparation labeled with ${ }^{125} \mathrm{I}$ was always within one to twofold dilution of that of the original serum from which the preparation was isolated.

Binding of antibody and complement to cells. Addition of antibody and complement components to erythrocytes was carried out in $\mathrm{pH} 7.5$ barbital buffer, containing $0.1 \%$ gelatin, relative $\mathrm{NaCl} 0.075$ m. During addition of antibody, EDTA, $0.01 \mathrm{M}$, was present. Calcium and magnesium were present in the buffer used for addition of C. Cells plus IgG antibody were incubated $30 \mathrm{~min}$ at $37^{\circ} \mathrm{C}$ followed by $30 \mathrm{~min}$ at $0^{\circ} \mathrm{C}$. After washing, the EA were incubated with human $\operatorname{IgM}$ for $30 \mathrm{~min}$ at $37^{\circ} \mathrm{C}$ and then washed with buffer containing $\mathrm{Ca}^{++}$and $\mathrm{Mg}^{++}$. After addition of $\mathrm{C} 1$ the cells were incubated at $0^{\circ} \mathrm{C}$ for $1 \mathrm{hr}$ and again washed. Components $\mathrm{C} 4, \mathrm{C} 2$, and $\mathrm{C} 3$ were added sequentially with incubation at $30^{\circ} \mathrm{C}$ for $30 \mathrm{~min}$ after each component and washing at $0^{\circ} \mathrm{C}$ between each step. The number of molecules of antibody bound to sheep cells was determined by incubating $0.5 \mathrm{ml}$ of a series of dilutions of rabbit ${ }^{125}$ I-labeled $\operatorname{IgG}$ with $0.5 \mathrm{ml}$ of sheep cells, $1.0 \times 10^{7} / \mathrm{ml}$. After washing three times with

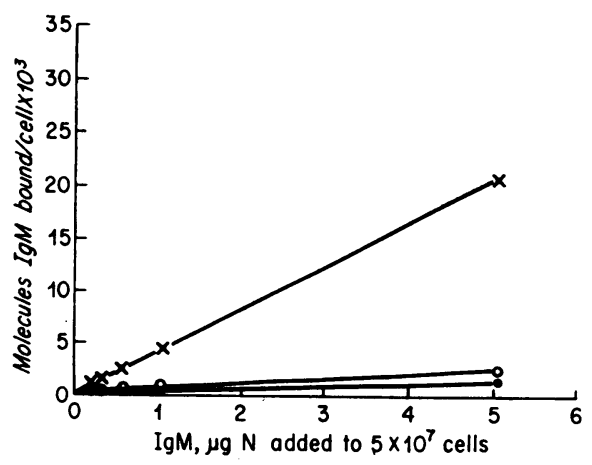

Figure 2 Binding of normal and rheumatoid human ${ }^{125}$ I-labeled IgM to sheep erythrocytes coated with 34,000 molecules IgG antibody per cell (EA). (X), rheumatoid IgM bound to EA; (O), rheumatoid $\operatorname{IgM}$ bound to $\mathrm{E}$; (๑), normal IgM bound to EA. 
the buffer the cells were counted in a Packard autogamma scintillation counter (Packard Instrument Co., Downers Grove, Ill.). Counts in tubes not containing cells were subtracted. These "glass binding" counts were always less than $5 \%$ of the counts added. The determinations of bound $\mathrm{RF}$ and $\mathrm{C} 3$ were made by the same technique except that the buffer used for C3 did not contain EDTA. Appropriate controls for nonspecific binding by $\mathrm{E}, \mathrm{EA}$, or $\mathrm{EAC}_{1,4}$ were performed as well as controls of normal, nonimmune rabbit IgG, or human IgM. Binding of $\mathrm{Cl}$ to EAC was determined by the $\mathrm{C} 1$ transfer test of Borsos and Rapp (11).

Phagocytosis. We employed the method of Gigli and Nelson (14) in which sheep erythrocytes coated with antibody and complement were phagocytized by rabbit neutrophils. Nonphagocytized cells were measured by lysis with distilled water since the erythrocytes within granulocytes were protected. A portion of appropriately coated sheep erythrocytes, $0.5 \mathrm{ml}$ containing $2.5 \times 10^{2}$ cells in $0.075 \mathrm{M}$ relative $\mathrm{NaCl}$ barbital buffer, was incubated with $3.0 \mathrm{ml}$ of rabbit granulocytes containing $2-3 \times 10^{7}$ cells in Hanks' solution, and the mixture tumbled for $1 \mathrm{hr}$ at $37^{\circ} \mathrm{C}$. Then $5.0 \mathrm{ml}$ of distilled water was added, the cells centrifuged, and the OD of the supernates determined at $415 \mathrm{~nm}$ in a spectrophotometer. Appropriate controls of granulocytes alone and uncoated erythrocytes plus granulocytes were prepared as well. The number of cells phagocytized was calculated as :

$\begin{aligned} & \mathrm{OD} \text { (test mixture) }-\mathrm{OD} \text { (granulocytes) } \\ &-\mathrm{OD} \text { (EA, spontaneous lysis) } \\ & \mathrm{OD}\left(\mathrm{EA}+\mathrm{H}_{2} \mathrm{O}\right)-\mathrm{OD} \text { (E.A. spontaneous lysis) }\end{aligned}$

where

$$
\mathrm{F}=\frac{1}{\mathrm{OD} \text { of } 1 \mathrm{~F}}
$$

\section{RESULTS}

Binding of antibody and RF to cells. Figs. 1 and 2 show representative examples of the binding data obtained for rabbit IgG antibody to $\mathrm{E}$ and rheumatoid IgM to EA. The very low blank values obtained for normal IgG and IgM with $E$ and EA respectively establish the validity of the method for the measurement of antisheep cell antibody and RF. In subsequent experiments reference curves such as those shown were used in calculating the amount of unlabeled antibody or RF bound to cells.

Effect of IgM RF on phagocytosis. Fig. 3 shows the effect of rheumatoid IgM on phagocytosis of cells coated with 195,000 molecules IgG antibody per cell, an amount which represents the optimum needed for complement fixation. Human $\operatorname{IgM}$ was added to the cells after antibody and before $\mathrm{C} 1$. Little inhibition of phagocytosis was produced by normal IgM, even at a concentration of $10 \mu \mathrm{g}$ protein $\mathrm{N}$. Rheumatoid $\operatorname{IgM}$ on the other hand, at a concentration as low as $0.5 \mu \mathrm{g} \mathrm{N}$ (resulting in 2500 molecules bound per cell), produced striking inhibition of phagocytosis to the base line level. When the amount of IgG antibody was reduced by $85 \%$ to 34,000 molecules bound per cell, a similar inhibitory effect was seen

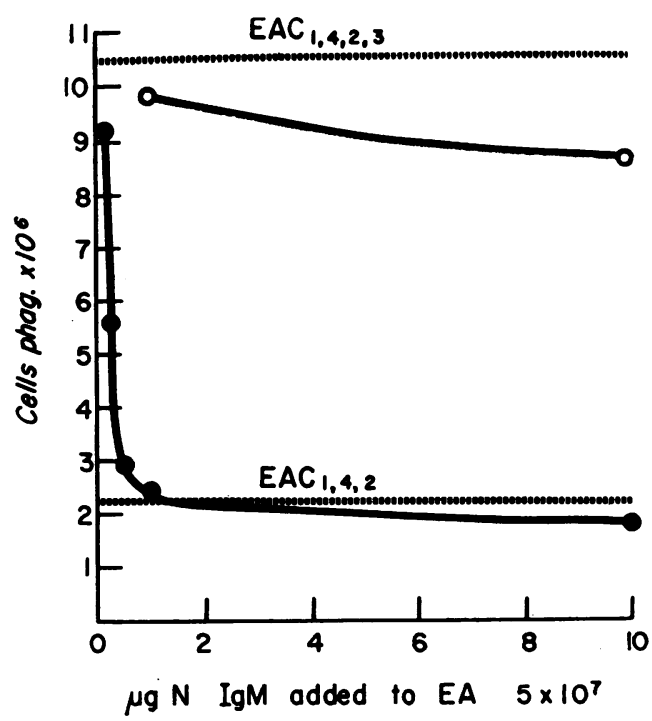

FIGURE 3 Inhibition of phagocytosis by rheumatoid IgM of EA coated with 195,000 molecules IgG antibody per cell. Complement components used per cell were $\mathrm{C} 1,100 \mathrm{EM}$; C2, 75 EM; C4, 100 EM; C3 $\left(\beta_{1 c}\right) 280$ molecules. (O), normal IgM; (๑), rheumatoid IgM.

as shown in Fig. 4. About twice as much rheumatoid IgM, $1.0 \mu \mathrm{g} \mathrm{N}$, was needed to produce comparable inhibition, but this amount added actually resulted in the same amount of bound RF, 2400 molecules per cell. The results shown were obtained with 9500 molecules of C3 $\left(\beta_{1 \mathrm{c}}\right)$ per cell, a larger amount than was employed in Fig. 3. However, very similar results were obtained when a smaller amount of C3 $\left(\beta_{1 \mathrm{c}}\right)$ was employed, 280 molecules per cell.

Role of complement components in inhibition of phagocytosis (high input of IgG antibody). In order to determine whether the inhibitory effect of rheumatoid IgM on phagocytosis which we had observed was mediated through an effect on the complement system, we examined the fixation of complement components to cells coated with 195,000 molecules of antibody per cell and treated with rheumatoid IgM before addition of complement components. Fig. 5 demonstrates that inhibition of phagocytosis (Fig. 3) was almost exactly paralleled by inhibition of binding of ${ }^{20} \mathrm{I}$-labeled C3 (Fig. 5). To answer the question of whether inhibition of $\mathrm{C} 3$ binding reflected a direct effect on $\mathrm{C} 3$ binding or inhibition of an earlier step in the complement sequence, $\mathrm{C} 1$ transfer tests on $\mathrm{EAC}_{1}$ made with normal and rheumatoid $\operatorname{IgM}$ were carried out. Fig. 6 shows that when a high input of rabbit IgG antibody was employed $(195,000$ molecules per cell) $\mathrm{C} 1$ uptake was almost completely inhibited by as little as $0.5 \mu \mathrm{g} \mathrm{N}$ of rheumatoid IgM, the same amount required to block complement-dependent phagocytosis and $\mathrm{C} 3$ uptake completely (Figs. 3 and 5 ). 


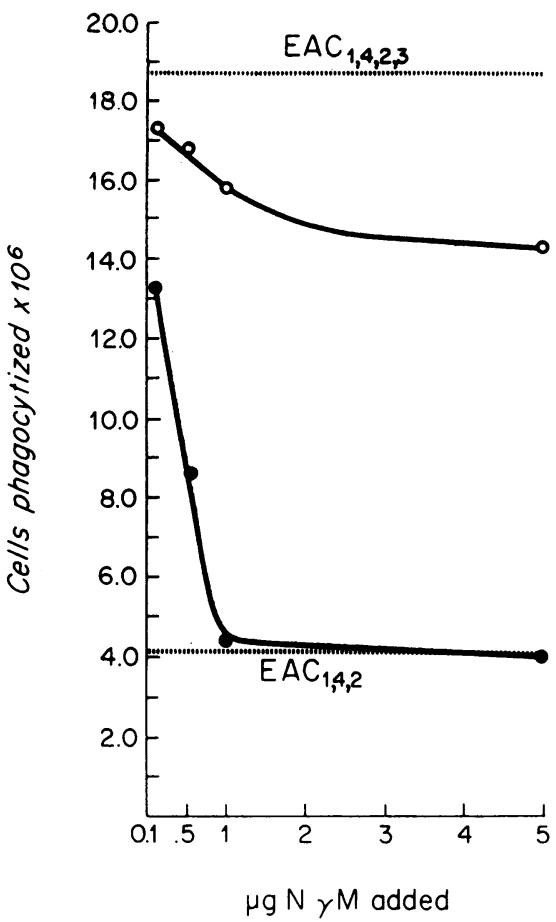

FigURe 4 Inhibition of phagocytosis by rheumatoid IgM of EA coated with 34,000 molecules $\operatorname{IgG}$ antibody per cell. Complement components used were same as in 3 except C3 $\left(\beta_{1 c}\right) 9500$ molecules. (O), normal IgM; (•), rheumatoid IgM.

Role of complement components in inhibition of phagocytosis (low input of IgG antibody). When the above experiments were repeated with cells coated with only one-sixth as much IgG antibody it was found that whereas C3 uptake was similarly inhibited by RF, C1 uptake was not. Table I demonstrates that $\mathrm{C} 1$ uptake as measured by transfer test was only very slightly inhibited by addition of $\mathrm{RF}$ at low levels of $\mathrm{Cl}$ input (100 EM per cell) and not at all at high $\mathrm{C} 1$ input (1000 EM per cell). In additional experiments (Table II) in which

TABLE I

Effect of RF on C1 Uptake by Cells Having Low Input of IgG Antibody

\begin{tabular}{ccc}
\hline Order of addition & $\begin{array}{c}\text { EM C1 } \\
\text { added per cell }\end{array}$ & $\begin{array}{c}\text { EM C1 } \\
\text { bound per cell }\end{array}$ \\
\hline EA + C1 & 100 & 42 \\
$\mathrm{EA}+\mathrm{RF}+\mathrm{C} 1$ & 100 & 34 \\
$\mathrm{EA}+\mathrm{C} 1+\mathrm{RF}$ & 100 & 34 \\
$\mathrm{EA}+\mathrm{C} 1$ & 1000 & 914 \\
$\mathrm{EA}+\mathrm{RF}+\mathrm{C} 1$ & 1000 & 1000 \\
$\mathrm{EA}+\mathrm{C} 1+\mathrm{RF}$ & 1000 & 914 \\
\hline
\end{tabular}

EA coated with 34,000 molecules IgG antibody per cell. $\mathrm{RF}=$ rheumatoid $\mathrm{IgM}, 1.0 \mu \mathrm{g} \mathrm{N}$, added to $5 \times 10^{7} \mathrm{EA}$.
TABLE II

Effect of $R F$ on Binding of $C 2$

\begin{tabular}{lccc}
\hline \multicolumn{1}{c}{ Cells } & $\begin{array}{c}\text { EM C2 } \\
\text { per cell in } \\
\text { supernate }\end{array}$ & $\begin{array}{c}\text { EM C2 } \\
\text { bound per cell }\end{array}$ & $\begin{array}{c}\text { C2 } \\
\text { bound }\end{array}$ \\
\hline None & & & $\%$ \\
$\mathrm{EA}+\mathrm{C} 2$ & $(96)$ & & \\
$\mathrm{EA}+\mathrm{RF}+\mathrm{C} 2$ & 88 & 0 & 0 \\
$\mathrm{EA}+\mathrm{RF}+\mathrm{C} 1+\mathrm{C} 4+\mathrm{C} 2$ & 68 & 4 & 5 \\
$\mathrm{EA}+\mathrm{C} 1+\mathrm{RF}+\mathrm{C} 4+\mathrm{C} 2$ & 64 & 24 & 22 \\
$\mathrm{EA}+\mathrm{C} 1+\mathrm{C} 4+\mathrm{RF}+\mathrm{C} 2$ & 39 & 49 & 25 \\
$\mathrm{EA}+\mathrm{C} 1+\mathrm{C} 4+\mathrm{C} 2$ & 38 & 50 & 57 \\
\hline
\end{tabular}

34,000 molecules IgG antibody per cell.

$\mathrm{RF}=$ rheumatoid $\operatorname{IgM}, 1.0 \mu \mathrm{g} \mathrm{N}$, added to $5 \times 10^{7}$ cells. $\mathrm{Cl}, \mathrm{C} 4$, and $\mathrm{C} 2,100 \mathrm{EM}$ of each added per cell.

$\mathrm{RF}$ was added at different steps of the complement sequence, it was found that addition of $\mathrm{RF}$ after $\mathrm{C} 4$ did not affect $\mathrm{C} 2$ uptake as measured by titration of residual $\mathrm{C} 2$. Nor did addition of $\mathrm{RF}$ after $\mathrm{C} 2$ affect uptake of $\mathrm{C} 3$ as determined by binding of ${ }^{125} \mathrm{I}$-labeled C3. Table III, however, demonstrates that binding of $\mathrm{C} 4$ by $\mathrm{EA}$ was

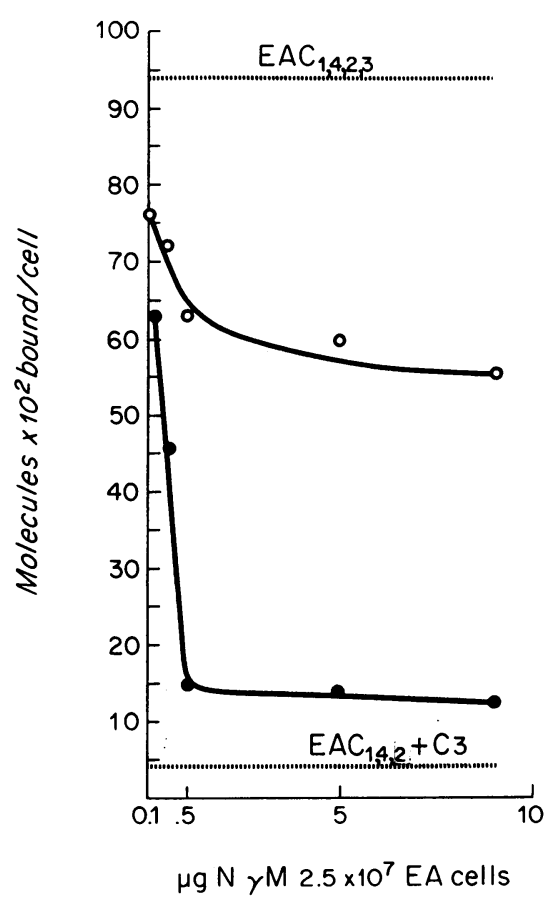

FIGURE 5 Effect of RF on binding of C3 $\left(\beta_{1 \mathrm{c}}\right)$. Antibody and complement components same as in Fig. 4. Line labeled $\mathrm{EAC}_{\mathbf{1 , 4}}$ $+\mathrm{C} 3$ represents nonspecific binding of $\mathrm{C} 3$ to $\mathrm{EAC}_{1,4}$. Line labeled $E A C_{1,4,2,3}$ represents specific binding of $C 3$ to $E A C_{1,4,2}$. $(O)$, binding of $\mathrm{C} 3\left(\beta_{1 \mathrm{c}}\right)$ to $\mathrm{EAC}_{1,4,2,3}$ to which normal IgM had been added; $(\theta)$, binding of $C 3\left(\beta_{1 c}\right)$ to $\mathrm{EAC}_{1,4,2,3}$ to which rheumatoid IgM had been added. 
impaired, even when $\mathrm{RF}$ was added after $\mathrm{C} 1$. Thus although EAC, not treated with IgM, bound 66 molecules $\mathrm{C} 4$ per cell, addition of $\mathrm{RF}$ after $\mathrm{C} 1$ reduced $\mathrm{C} 4$ binding to 26 molecules per cell, a result suggesting interference by $\mathrm{RF}$ of binding of $\mathrm{C} 4$ to antibody.

Effect of human C1. The above experiments were performed with partially purified guinea pig $\mathrm{C} 1$ as a source of the first component of complement. Zvaifler and Bloch (26) found that RF inhibited uptake of guinea pig complement at $4^{\circ}$ and $37^{\circ} \mathrm{C}$ yet was able to fix human complement at $37^{\circ}$ but not $4^{\circ} \mathrm{C}$. We therefore examined the effect of $\mathrm{RF}$ on phagocytosis of cells first coated with human $\mathrm{C} 1$ at $37^{\circ} \mathrm{C}$. The results of Table IV show that $\mathrm{RF}$ added before or after human $\mathrm{C} 1$ inhibited phagocytosis of such cells about equally as well as cells made with guinea pig C1 (compare Fig. 4).

\section{DISCUSSION}

Phagocytosis of microorganisms, erythrocytes, or other particles by polymorphonuclear granulocytes is markedly enhanced by the addition of antibody and complement. Indeed whether antibody alone in the absence of complement is capable of promoting phagocytosis is not entirely certain. Although a specific binding site for IgG antibodies has been clearly demonstrated on the surface of the macrophage (15) it has been more difficult to establish the presence of such a site on granulocytes. Messner and Jelinek have presented evidence for such a specific receptor site for the Fc portion of $\gamma \mathrm{G}$-globulin on the surface of human neutrophils (16). However these authors were only able to achieve binding of Rh-positive erythrocytes to neutrophils by using a particular hyperimmune complement-fixing anti-Rh (Ripley) and not with ordinary anti-Rh sera. Even when purified IgG and thoroughly washed granulocytes are used in phagocytic assays it is difficult to exclude participation of small amounts of complement bound to leukocytes. Golden and McDuffie (17), for example, found that inhibition of lupus erythematosus cell formation could be achieved with anti-complement antiserum in a phagocytic system in which complement could not be detected by ordinary means. Although factors other than complement may be responsible for the enhancing effect of fresh serum on phagocytosis none has as yet been unequivocally identified. Gigli and Nelson (14) showed that addition of C1, $\mathrm{C} 2$, or $\mathrm{C} 4$ had no effect on phagocytosis whereas addition of $\mathrm{C} 3$ produced a marked enhancement, not affected by addition of the subsequently reacting components, C5-C9.

Thus it is not surprising that IgM RF which blocks complement fixation by IgG antibodies is able to inhibit phagocytosis of particles coated with antibody and complement. Messner, Lasdal, Quie, and Williams (5) have previously shown that IgM RF isolated from patients with subacute bacterial endocarditis (SBE) was able to

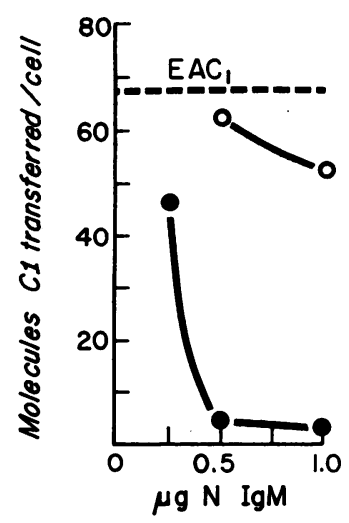

Figure 6 Effect of RF on binding of $\mathrm{C} 1$ to EA coated with 195,000 molecules of antibody per cell. $100 \mathrm{EM} \mathrm{C1}$ added per cell. (O), normal IgM ; (๑), rheumatoid IgM.

inhibit ingestion by polymorphonuclear leukocytes of bacteria coated with IgG opsonin. If RF was added to antibody-coated bacteria before addition of fresh normal serum the effect was more pronounced than if it was added after fresh serum. The present experiments clearly demonstrate that this effect is mediated through inhibition of $\mathrm{C} 1$ and $\mathrm{C} 4$ uptake by antigen-antibody complexes. Presumably the inhibition of $\mathrm{C} 1$ uptake is the result of competition between $\mathrm{RF}$ and $\mathrm{Clq}$ for the same site or adjacent sites on the Fc portion of $\operatorname{IgG}(18,19)$.

We cannot explain why inhibition of $\mathrm{C} 1$ fixation by $\mathrm{RF}$ was so much more pronounced when cells heavily coated with antibody were used. Aho, Harboe, and Leikola (20) found that the agglutination by RF of sheep cells coated with small amounts of IgG could be inhibited

TABLE III

Effect of RF on C4 Uptake by Cells Having Low Input of IgG Antibody

\begin{tabular}{|c|c|c|c|}
\hline \multicolumn{4}{|c|}{100 EM C4 added per cell } \\
\hline Order of addition & $\begin{array}{c}\text { EM C4 } \\
\text { per cell in } \\
\text { supernate }\end{array}$ & $\begin{array}{c}\text { EM C4 } \\
\text { bound per cell }\end{array}$ & $\begin{array}{c}\mathrm{C} 4 \\
\text { bound }\end{array}$ \\
\hline & & & $\%$ \\
\hline EA & 82 & 0 & 0 \\
\hline $\mathrm{EA}+\mathrm{C} 4$ & 82 & 0 & 0 \\
\hline $\mathrm{EA}+\mathrm{RF}+\mathrm{C} 4$ & 82 & 0 & 0 \\
\hline $\mathrm{EA}+\mathrm{C} 1+\mathrm{C} 4$ & 16 & 66 & 80 \\
\hline $\mathrm{EA}+\mathrm{C} 1+\mathrm{RF}+\mathrm{C} 4$ & 56 & 26 & 32 \\
\hline $\mathrm{EA}+\mathrm{RF}+\mathrm{C} 1+\mathrm{C} 4$ & 74 & 8 & 10 \\
\hline
\end{tabular}

EA coated with 34,000 molecules IgG antibody per cell. $\mathrm{RF}=$ rheumatoid $\operatorname{IgM}, 1.0 \mu \mathrm{g} \mathrm{N}$, added to $5 \times 10^{7}$ cells. C1, $100 \mathrm{EM}$ per cell. $100 \mathrm{EM} \mathrm{C4}$ added per cell and after centrifugation residual $\mathrm{C} 4$ determined in the supernate by hemolytic titration. Bound $\mathrm{C} 4$ determined by subtraction of appropriate controls. 
TABLE IV

Effect of RF on Phagocytosis (Human C1)

\begin{tabular}{|c|c|c|}
\hline Order of addition & $\begin{array}{l}\text { Cells } \\
\text { phagocytized } \\
\times 10^{6}\end{array}$ & $\begin{array}{c}\text { Cells } \\
\text { phagocytized }\end{array}$ \\
\hline & & $\%$ \\
\hline $\mathrm{EAC}_{1,4,2}$ & 1.25 & 5 \\
\hline $\mathrm{EAC}_{1,4,2,3}$ & 12.0 & 48 \\
\hline $\mathrm{EA}+\mathrm{N} \operatorname{Ig} \mathrm{M}+\mathrm{C} 1,4,2,3$ & 9.3 & 37 \\
\hline $\mathrm{EAC}_{1}+\mathrm{N} \operatorname{IgM}+\mathrm{C} 4,2,3$ & 9.8 & 39 \\
\hline $\mathrm{EA}+\mathrm{RF}+\mathrm{C} 1,4,2,3$ & 2.5 & 10 \\
\hline $\mathrm{EAC}_{1}+\mathrm{RF}+\mathrm{C} 4,2,3$ & 7.0 & 28 \\
\hline
\end{tabular}

34,000 molecules IgG antibody per cell. EM added per cell were $100 \mathrm{Cl}, 75 \mathrm{C} 4$, and $50 \mathrm{C} 2.200$ molecules $\mathrm{C} 3\left(\beta_{1 \mathrm{c}}\right)$ added per cell.

$1.0 \mu \mathrm{g} \mathrm{N}$ RF or normal IgM per cell.

by native IgG in serum, but agglutination of heavily coated cells could only be inhibited with aggregated IgG such as that in an immune precipitate. Whether the greater affinity of RF to heavily coated cells reflects only the involvement of more binding sites (out of a possible total of five on the $\operatorname{IgM}$ molecule) or a configurational change occurring on the $\mathrm{IgG}$ antibody after its reaction with red cell antigens cannot be answered. $\mathrm{Clq}$ is also multivalent, and $\mathrm{Cl}$ binds to $\mathrm{EA}$ more strongly as the number of IgG molecules on the cell surface is increased (21). A similar mechanism of competition may account for the inhibition of $\mathrm{C} 4$ uptake which we observed at lower levels of antibody input, since $\mathrm{C} 4$ is known to bind to an as yet unidentified site on antibody (22). Since C2 binds directly to $\mathrm{C} 4$ to form a complex which acts in turn to activate or bind $\mathrm{C} 3$, failure of $\mathrm{RF}$ to inhibit binding of $\mathrm{C} 2$ when added after $\mathrm{C} 4$ is not surprising (23). Although $\mathrm{C} 3$ or $\beta_{1 \mathrm{c}}$ may bind directly to immunoglobulin (24) it may also attach to the surface of sensitized erythrocytes (25), a phenomenon which may explain failure of $\mathrm{RF}$ to inhibit $\mathrm{C} 3$ binding when added to $\mathrm{EAC}_{1, \mathbf{4}, \mathbf{2}}$.

IgM RF has previously been shown to interfere with fixation of complement by IgG antibodies $(26,27)$. Zvaifler and Schur (28) found that the complex formed between RF and mercaptoethanol-treated aggregated IgG (which reacts with RF but does not itself fix complement) did not consume human or guinea pig complement when the complex was added to fresh rheumatoid serum. Large amounts ( $>1.0 \mathrm{mg}$ ) or preformed complexes of RF and mercaptoethanol-treated IgG were, however, able to fix human but not guinea pig complement. In our experiments we found RF equally inhibited phagocytosis of cells coated with either human or guinea pig C1. Schmid, Roitt, and Rocha (29) found that, whereas RF inhibited complement fixation of sheep cells optimally sensitized with IgG antibody, some complement fixation by RF occurred when cells coated with suboptimal amounts of antibody were used. In the present experiments, however, reduction in the amount of IgG antibody used to coat sheep cells to $15 \%$ of the optimal amount did not significantly reduce the complement uptake nor the amount of phagocytosis observed. The complement-fixing activity of RF must be weak at best, even under carefully controlled conditions.

The mechanism by which RF inhibits complement fixation remains obscure. No significant structural differences between IgM RF and other human IgM globulins have so far been detected $(30,31)$. Yet IgM antibodies of most species fix complement and promote phagocytosis more efficiently than IgG antibodies (32-34). MacKenzie, Creevy, and Heh (35) have reported that some Ig M myeloma globulins bind $\mathrm{Clq}$ to a much lesser extent than normal. Possibly RF contains a high proportion of such antibodies since we found that inhibition of $\mathrm{C} 1$ fixation was virtually complete when optimally sensitized cells were pretreated with RF. The explanation for the inhibitory effect on $\mathrm{C} 4$ binding is not apparent from our data although it has been found that $\operatorname{Ig} M$ antibodies are less efficient than IgG antibodies in the titration of $\mathrm{C} 4$ (36). Human IgM antinuclear antibodies in our experience also appear to be deficient in their ability to fix complement and to promote phagocytosis (37). Most of the previous work on inhibition of complement fixation by $\mathrm{RF}$ has employed inhibition of immune hemolysis as an indicator so that no one has excluded the possibility that $\mathrm{RF}$ may fix complement at a position sufficiently distant from the cell surface so that, in spite of activation of the components, cell lysis may not occur. The present experiments clearly show that activation and binding of the first four steps of the complement sequence are actually prevented by $R F$.

These results imply that circulating IgM RF does not play a significant role in the inflammation of vessels and tissues in RA, since the phlogistic effects of $\operatorname{IgM}$ antibodies are probably mediated largely through the complement system. Though immune complexes appear to be responsible for the low levels of complement in synovial fluid (38), pleural fluid (39), and serum ${ }^{2}$ of rheumatoid patients, IgM RF itself does not seem to be the major antibody in these complexes. Winchester, Agnello, and Kunkel (38) found only IgG and not IgM in the high molecular weight material in rheumatoid synovial fluid which they were able to relate to complement depletion. Horwitz, Garrett, and Davis (40) found that rheumatoid IgM inhibited rather than enhanced release of complement-derived chemotactic activity. In experiments with passive immune synovitis in the rabbit knee joint we have not found any consistent enhancing effect of

\footnotetext{
${ }^{2}$ Hunder, G. G., and F. C. McDuffie. Hypocomplementemia in rheumatoid arthritis. Unpublished observations.
} 
$\mathrm{RF}$ on the inflammatory reaction, slight inhibition or no effect being the usual result. ${ }^{3}$ On the other hand Tesar, Schmid, and Suarey (41) have pointed out that RF vary in avidity for antigen and that those of high avidity fix complement better than those of low avidity. Thus it is possible that a small proportion of RF of particularly high avidity may be contributing to tissue damage.

\section{ACKNOWLEDGMENTS}

This study was supported by the National Institute of Arthritis and Metabolic Diseases, Research Grant AM11630.

\section{REFERENCES}

1. Hollander, J. L., D. J. McCarty, Jr., G. Astorga, and E. Castro-Murillo. 1965. Studies on the pathogenesis of rheumatoid joint inflammation. I. The "RA cell" and a working hypothesis. Ann. Intern. Med. 62: 271.

2. Restifo, R. A., A. J. Lussier, A. J. Rawson, J. H. Rockey, and J. L. Hollander. 1965. Studies on the pathogenesis of rheumatoid joint inflammation. III. The experimental production of arthritis by the intra-articular injection of purified 7S gamma globulin. Ann. Intern. Med. $62: 285$.

3. Sliwinski, A. J., and N. J. Zvaifler. 1969. The removal of aggregated and nonaggregated autologous gamma globulin from rheumatoid joints. Arthritis Rheum. 12: 504.

4. Davis, J. S., IV. 1966. A hypothetical common mechanism in systemic lupus erythematosus and rheumatoid arthritis. Arthritis Rheum. 9: 631.

5. Messner, R. P., T. Ladal, P. G. Quie, and R. C. Williams, Jr. 1968. Serum opsonin, bacteria, and polymorphonuclear leukocyte interactions in subacute bacterial endocarditis. Anti- $\gamma$-globulin factors and their interaction with specific opsonins. J. Clin. Invest. 47: 1109.

6. Nelson, R. A., J. Jensen, I. Gigli, and N. Tamura. 1966. Methods for the separation, purification and measurement of nine components of hemolytic complement in guinea-pig serum. Immunochemistry. 3: 111.

7. Müller-Eberhard, H. J., U. Nilsson, and T. Aronsson. 1960. Isolation and characterization of two $\beta_{1}$-glycoproteins of human serum. J. Exp. Med. 111: 201.

8. Nilsson, U. R., and H. J. Müller-Eberhard. 1965. Isolation of $\beta_{1 \mathrm{~F}}$-globulin from human serum and its characterization as the fifth component of complement. J. Exp. Med. $122: 277$.

9. Müller-Eberhard, H. J., and C. E. Biro. 1963. Isolation and description of the fourth component of human complement. J. Exp. Med. 118: 447.

10. Mayer, M. M. 1961. Complement and complement fixation. In Kabat and Mayer's Experimental Immunochemistry. Charles C. Thomas, Publisher, Springfield, Ill. 2nd edition. 133.

11. Borsos, T., and H. J. Rapp. 1965. Hemolysin titration based on fixation of the activated first component of complement: evidence that one molecule of hemolysin suffices to sensitize an erythrocyte. J. Immunol. 95: 559.

12. Nelson, R. A., Jr. 1953. The immune-adherence phenomenon. An immunologically specific reaction between microorganisms and erythrocytes leading to enhanced phagocytosis. Science (Wash. D. C.). 118: 733 .

\footnotetext{
${ }^{3}$ Ramirez-Peredo, J., and F. C. McDuffie. Unpublished observations.
}

13. McConahey, P. J., and F. J. Dixon. 1966. A method of trace iodination of proteins for immunologic studies. Int. Arch. Allergy Appl. Immunol. 29: 185.

14. Gigli, I., and R. A. Nelson, Jr. 1968. Complement dependent immune phagocytosis. I. Requirements for $C^{\prime} 1$, $\mathrm{C}^{\prime} 4, \mathrm{C}^{\prime} 2$ and $\mathrm{C}^{\prime} 3$. Exp. Cell Res. 51: 45.

15. Berken, A., and B. Benacerraf. 1966. Properties of antibodies cytophilic for macrophages. J. Exp. Med. 123: 119.

16. Messner, R. P., and J. Jelinek. 1970. Receptors for human $\gamma \mathrm{G}$ globulin on human neutrophils. J. Clin. Invest. $49: 2165$.

17. Golden, H. E., and F. C. McDuffie. 1967. Role of lupus erythematosus factor and accessory serum factors in production of extracellular nuclear material. Ann. Intern. Med. $67: 780$.

18. Schubart, A. F., and R. W. Ewald. 1965. Kinetic studies of serum complement components creating inhibition of the agglutination activating activity of the rheumatoid factor. Arthritis Rheum. 8: 467. (Abstr.)

19. Ewald, R. W., and A. F. Schubart. 1966. Agglutinating activity of the complement component $C^{\prime} 1 \mathrm{q}$ in the F-II latex fixation test. J. Immunol. $97: 100$.

20. Aho, K., M. Harboe, and J. Leikola. 1964. Studies of the antibody nature of the rheumatoid factor. Reaction of the rheumatoid factor with sheep erythrocytes sensitized with human anti-sheep cell antibodies and with 0 $\mathrm{Rh}$ positive cells sensitized with incomplete anti- $\mathrm{Rh}$ antibodies. Immunology. 7: 403.

21. Linscott, W. D. 1970. Complement fixation: the effects of $\mathrm{IgG}$ and $\operatorname{IgM}$ antibody concentration of C1-binding affinity. J. Immunol. 105 : 1013.

22. Willoughby, W. F., and M. M. Mayer. 1965. Antibodycomplement complexes. Science (Wash. D. C.). 150: 907.

23. Müller-Eberhard, H. J., M. J. Polley, and M. A. Calcott. 1967. Formation and functional significance of a molecular complex derived from the second and the fourth component of human complement. J. Exp. Med. $125: 359$.

24. Leddy, J. P., R. F. Bakemeier, and J. H. Vaughan. 1965. Fixation of complement components to autoantibody eluted from human RBC. J. Clin. Invest. 44: 1066. (Abstr.)

25. Müller-Eberhard, H. J., A. P. Dalmasso, and M. A. Calcott. 1966. The reaction mechanism of $\beta_{1 \mathrm{c}}$-globulin $\left(C^{\prime} 3\right)$ in immune hemolysis. J. Exp. Med. 123: 33.

26. Zvaifler, N. J., and K. J. Bloch. 1962. Rheumatoid factor-an inhibitor of the complement fixation reaction. Arthritis Rheum. 5: 127. (Abstr.)

27. Heimer, R., F. M. Levin, and M. F. Kahn. 1963. Inhibition of complement fixation by human serum. II. The activity of a $\gamma-1 \mathrm{~m}$ globulin and rheumatoid factor on complement fixation reactions. J. Immunol. 91: 866.

28. Zvaifler, N. J., and P. Schur. 1968. Reactions of aggregated mercaptoethanol treated gamma globulin with rheumatoid factor-precipitin and complement fixation studies. Arthritis Rheum. $11: 523$.

29. Schmid, F. R., I. M. Roitt, and M. J. Rocha. 1970. Complement fixation by a two-component antibody system: immunoglobulin $G$ and immunoglobulin $M$ antiglobulin (rheumatoid factor). J. Exp. Med. 132: 673.

30. Kunkel, H. G., E. C. Franklin, and H. J. Müller-Eber- 
hard. 1959. Studies on the isolation and characterization of the "rheumatoid factor." J. Clin. Invest. 38: 424.

31. Heimer, R., K. R. Woods, and R. L. Engle, Jr. 1962. Amino acid analyses of rheumatoid factors and normal gammaglobulins. Proc. Soc. Exp. Biol. Med. 110: 496.

32. Onoue, K., N. Tanigaki, Y. Yagi, and D. Pressman. 1965. IgM and IgG anti-hapten antibody: hemolytic hemagglutinating and precipitating activity. Proc. Soc. Exp. Biol. Med. 120: 340 .

33. Robbins, J. B., K. Kenny, and E. Suter. 1965. The isolation and biological activities of rabbit $\gamma \mathrm{M}-$ and $\gamma \mathrm{G}$ anti-Salmonella typhimurium antibodies. J. Exp. Med. 122: 385 .

34. Rowley, D., and K. J. Turner. 1966. Number of molecules of antibody required to promote phagocytosis of one bacterium. Nature (Lond.). 210: 496.

35. MacKenzie, M. R., N. Creevy, and M. Heh. 1971. The interaction of human $\mathrm{IgM}$ and C1q. J. Immunol. 106: 65.

36. Frank, M. M., and T. Gaither. 1970. Evidence that rabbit $\gamma \mathrm{G}$-haemolysin is capable of utilizing guinea-pig complement more efficiently than rabbit $\gamma \mathrm{M}$-haemolysin. Immunology. 19: 975.

37. Blondin, C., and F. C. McDuffie. 1970. Role of IgG and $\operatorname{IgM}$ antinuclear antibodies in formation of lupus erythematosus cells and extracellular material. Arthritis Rheum. 13: 786.

38. Winchester, R. J., V. Agnello, and H. G. Kunkel. 1970. Gamma globulin complexes in synovial fluids of patients with rheumatoid arthritis. Partial characterization and relationship to lowered complement levels. Clin. Exp. Immunol. 6: 689.

39. Hunder, G. G., F. C. McDuffie, and N. G. G. Hepper. 1972. Pleural fluid complement in systemic lupus erythematosus and rheumatoid arthritis. Ann. Intern. Med. $76: 357$.

40. Horwitz, D. A., M. A. Garrett, and J. S. Davis, IV. 1971. Modification of leukocyte chemotaxis by rheumatoid factor. Arthritis Rheum. 14: 388. (Abstr.)

41. Tesar, J. T., F. R. Schmid, and A. Suarey. 1972. Association of avidity of rheumatoid factor (RF) with complement fixation. Arthritis Rheum. 15: 128. (Abstr.) 